\title{
Biological control of soil-borne phytopathogenic fungi through onion waste composting: implications for circular economy perspective
}

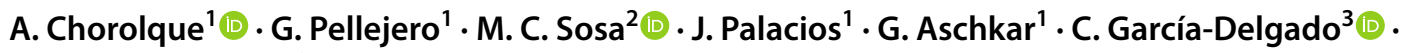 \\ R. Jiménez-Ballesta ${ }^{3}$ (i)
}

Received: 20 September 2020 / Revised: 8 June 2021 / Accepted: 19 July 2021 / Published online: 29 July 2021

(c) The Author(s) 2021, corrected publication 2021

\begin{abstract}
The production of onion waste derived mainly from bulbs affected by fungal diseases, during onion classification and storage presents an important agro-environmental issue in onion production regions. Composting is an environmentally friendly strategy to recycle agricultural waste and produce organic fertilizers. Modifications of the microbial community in soil can affect the ability of pathogen propagules to survive, germinate and infect plant roots. Hence, the main objective of this work was to exploring the mechanisms involved on the presence of three soil-borne phytopathogenic fungi during the composting process of onion waste under the hypothesis if that the resulting compost effectively prevents or minimizes the dispersion of phytopathogenic fungi. To this end, three composting piles of 60 tonnes each were built by layering onion waste affected by phytopathogenic fungi and cow dung at 1:1 ratio. Temperature, moisture, $\mathrm{pH}$, electrical conductivity (EC) and Aspergillus niger, Penicillium sp. and Fusarium sp. growth were monitored for 100 days. During the first 28 days of composting, the presence of phytopathogenic fungi increased significantly showing thereafter a downward trend. Final estimations of fungal populations densities indicated a predominance of A. niger and an effective reduction in the abundance of Fusarium sp. This pilot-scale work demonstrates the feasibility of composting onion waste contaminated with phytopathogenic fungi and highlights the positive environmental impact associated with this practice. Therefore, the composting of onion waste and cow dung is a feasible and sustainable procedure to recycle onion waste and to promote circular economy in onion production regions.
\end{abstract}

Keywords Onion $\cdot$ Phytopathogenic fungi $\cdot$ Biocontrol $\cdot$ Agricultural waste $\cdot$ Compost $\cdot$ Circular economy

\section{Introduction}

The commercialization of onion (Allium cepa L.) is usually done several months after harvesting. The storage and conditioning of onion produce large amounts of organic residues, due to cleaning and discard of bulbs affected by post-harvest fungi. The Valle Inferior de Río Negro region in Argentina has an onion cropping surface of 2000 ha (IDEVI 2016)

Editorial responsibility: M. Shabani.

$\triangle$ C. García-Delgado

carlos.garciadelgado@uam.es

1 CURZA - Universidad Nacional del Comahue, Río Negro, 8500 Viedma, Argentina

2 Facultad de Ciencias Agrarias, Universidad Nacional del Comahue, Rio Negro, Cinco Saltos, Argentina

3 Department of Geology and Geochemistry, Autonomous University of Madrid, 28049 Madrid, Spain and produces about $5000 \mathrm{~m}^{3}$ of onion waste per year. Postharvest diseases have a negative impact on onion quality and yield a substantial amount of agricultural waste because the affected bulbs are discarded. This agricultural waste is accumulated next to agro-industrial facilities or even in agricultural soils, with consequent dispersion of phytopathogenic fungi and the ensuing environmental impact (Pellejero et al. 2011). The European Commission introduced a new concept based on the recovery of materials, i.e., the "circular economy" in response to environmental and social problems. To promote circular economy, onion waste can be recycled by composting or vermicomposting to produce environmental friendly agricultural inputs such as organic fertilizers and amendments (Pellejero et al. 2017, 2020). Since agricultural wastes are a reservoir of valuable substances (organic carbon and nutrients), composting is an efficient and agroecological way to recycle organic wastes through aerobic biotransformation of organic materials into a stabilized end product, i.e., compost (Román et al. 2015; Vargas-Machuca 
et al. 2015). Application of compost to agricultural soils as organic fertilizer or amendment produces noticeable agronomic and environmental benefits. These include increased transfer of soil organic carbon and reduced use of chemical fertilizers, and attenuation of negative effects of pesticides on soil microbiota and its leaching (Mondini and Sequi 2008; Carpio et al. 2020a, b).

Microorganisms are responsible for most of the physicochemical changes that occur on organic wastes during composting, govern the conversion rate of organic waste and determine the final quality of the compost (Moreno-Casco and Mormeneo-Bernal 2011). Hence, a thorough knowledge of the microbial communities involved in the composting process is paramount. The microbial consortium is typically composed of combination of mesophilic and thermophilic microorganisms such as bacteria (especially Actinobacteria) as well as diverse fungi (Haseena et al. 2016). Multiple genera of filamentous fungi with high cellulase and ligninolytic activity were identified during green compost and vermicompost analyses (Anastasi et al. 2005; Haseena et al. 2016).

During the post-harvest management of onion, substantial economic loss may occur due to several fungal diseases. Aspergillus niger is the most common pathogenic fungus worldwide and is responsible for the black mold on onion bulbs (Kumar et al. 2015; Lee et al. 2001; Tyson and Fullerton 2004). In recent years, other post-harvest diseases such as blue mold by Penicillium spp., basal rot by Fusarium oxysporum and blossom end rot by Botrytis allii are increasingly affecting onion farming (Chorolque et al. 2018). F. oxysporum was reported as a pathogen of onion in field and storage (Sánchez et al. 2015). This fungus survives between consecutive onion crop cycles as a soil saprophyte, in bulbs or onion wastes (Lee et al. 2001; Samuel and Ifeanyi 2015; Tyson and Fullerton 2004) which means that the inoculum formed by conidia, mycelia or resistance structures remains in the onion processing zones and increases its presence over time. The application of composting wastes to agricultural soils can control the propagation of soil-borne phytopathogenic fungi by competition between compost and soil microbiota (de Ceuster \& Hoitink 1999; Pugliese et al. 2008). For example, the antagonist effect of the compost microbiota against the phytopathogenic fungi was reported in Sclerotium rolfsii (Hadar and Gorodecki 1991). Moreover, aerobic composting for 21 days with temperatures in excess of $70{ }^{\circ} \mathrm{C}$ and $40{ }^{\circ} \mathrm{C}$ during $10-15$ days eliminated Armillaria mellea, Rhizoctonia solani and Verticillium dahliae in green wastes (Yuen and Raabe 1984). In turn, the composting of onion wastes allowed effective control of Sclerotium cepivorum, which causes white rot in onion and garlic (Coventry et al. 2002; Entwistle 1990). However, there is still limited information regarding onion waste composting as a biocontrol strategy to prevent the dispersion of phytopathogenic fungi containing the discarded bulbs, as well as on the safety of the resulting compost upon application as organic fertilizer. Hence, characterization of the composting process of onion waste and assessment of the phytopathogenic load of the resulting compost are necessary to minimize the risk of dispersing phytopathogenic fungi upon its application into agricultural soil.

Along these lines, the aims of this work were (i) to assess the evolution of physicochemical parameters of the composting process and (ii) to determine the population kinetics of the main phytopathogenic fungi of onion crops during the composting process, to elucidate if the resulting compost could act as a dispersion agent. This work contributes to demonstrate a feasible strategy to recycle agricultural wastes with the further reduction of chemical inputs in agriculture and promoting circular economy and organic farming.

\section{Materials and methods}

\section{Composting method, location and experimental design}

In this study, we evaluated composting from two biowastes that result of regional agricultural activities and constitute a serious environmental problem: onion crops residues and cow dung. The composting has two purposes: To produce compost as a procedure to recycle onion waste promoting circular economy in onion production regions and to control soil-borne pathogens affecting the onion crop.

Compost can be produced from many different types of biowastes, including crop residues. Common methods of onfarm composting include static piles, windrows (elongated piles) and in-vessel (enclosed) composting (Cooperband 2002). The composting method used in the assays was windrows piles with aeration by means of periodic turns. This method is the most common among onion producers due to 

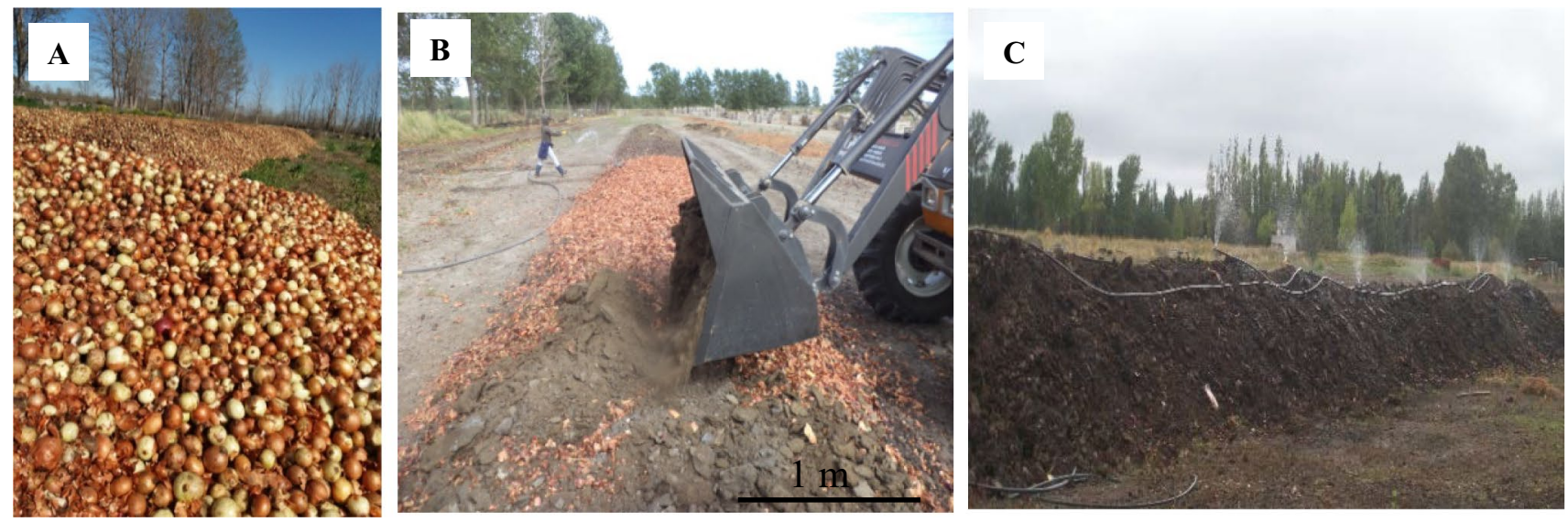

Fig. 1 General aspect of the onion waste $\mathbf{a}$, construction of composting piles by alternating layers of onion waste and cow dung $\mathbf{b}$ and irrigation system $\mathbf{c}$

the large amounts of residues they generate. Furthermore, the method is inexpensive and easy to implement.

For this, the assays were performed at pilot scale at the Mandurai S.A. facilities in San Javier, Argentina (40 ${ }^{\circ} 47^{\prime}$ $\left.\mathrm{S} ; 63^{\circ} 12^{\prime} \mathrm{W}\right)$. The discard from 180 ha of onion crop, i.e., cataphylls and bulbs affected by post-harvest fungi (Fig. 1a), was used to build the composting piles. Three composting piles $(30 \mathrm{~m}$ long $\times 3 \mathrm{~m}$ wide $\times 1.5 \mathrm{~m}$ high) were built by alternating layers of onion waste and cow dung (Fig. 1b). The final weight of each pile was approximately $60 \mathrm{t}$. The ratio of onion waste: cow dung was determined according to Rynk et al. (1992) to reach a final C/N ratio of 30. Cow dung is a suitable material to help the compost in the maturity process and was previously used to composting onion waste and other organic wastes (Pellejero 2015; Abdoli et al. 2019). The final ratio of onion waste:cow dung was 1.3:1 (w:w). $\mathrm{C}$ and $\mathrm{N}$ were determined by combustion (Bremner 1996). The moisture of the composting piles was kept constant by aspersion irrigation (Fig. 1c). The composting process took place for 100 days from March to May 2017.

\section{Sampling and physicochemical analysis}

Temperature was measured daily using a digital thermometer placed at a depth of $30 \mathrm{~cm}$ at different sites of the composting piles. Sampling was performed according to the recorded temperatures, indicative of the composting phases (i.e., thermophilic, mesophilic and maturation). Composite samples were taken from each pile, the days between one sampling and another vary depending on the phases of the composting process. One sampling was performed at the beginning of the process (day 0 ), four during the thermophilic phase $(9,20,28$ and 38 days) and six during the maturation phase (54, 65, 70, 77, 88 and 100 days). For each composting pile, three different composite samples (1 kg each) were obtained by mixing individual sub-samples from the central area and from two margins of the composting pile to a depth of $30 \mathrm{~cm}$. Moisture was determined by lost weight at $105^{\circ} \mathrm{C}$ whereas $\mathrm{pH}$ and $\mathrm{EC}$ were determined in 1:10 (w:v) extract using a pH meter (Hanna, HI-99141) and a conductivity meter (Hanna, HI-2316), respectively.

\section{Extraction and count of phytopathogenic fungi during composting}

Identification and count of phytopathogenic fungi were carried out using four sub-samples from composite samples obtained from each composting pile as described above. The extraction was performed by vigorously mixing $10 \mathrm{~g}$ of each sample in $90 \mathrm{~mL}$ of sterilized water, followed by serial dilution up to $10^{-6}$. Each sample was extracted in quadruplicate, to obtain a total of 12 samples for each sampling time. 
Aliquots $(1 \mathrm{~mL})$ of each dilution were inoculated per triplicate in petri dishes containing potato dextrose agar (PDA) and incubated at $24{ }^{\circ} \mathrm{C}$ for 7 days in the dark (Trombetta et al. 1998). The identification of colonies was performed according to macro- and microscopic morphological characteristics of fungi. Colony forming units (CFU) counts for each tested fungi (Aspergillus niger, Penicillium sp. and Fusarium sp.) were normalized against each dilution factor and the results expressed as CFU per gram of dry compost.

\section{Statistical analysis}

Moisture, $\mathrm{pH}$ and EC data were analyzed by one-way analysis of variance (ANOVA). Tukey post hoc test with a level of significance of $95 \%(p \leq 0.05)$ was used to determine differences between the three piles at both identical and successive sampling times. To determine temporal variations in phytopathogenic fungal populations during the composting process, the respective CFU count results were statistically evaluated by one-way ANOVA followed by Tukey post hoc test, with a significance threshold of $p \leq 0.05$. All the statistical analyses were performed using INFOSTAT software (FCA, UNC, Córdoba, Argentina).
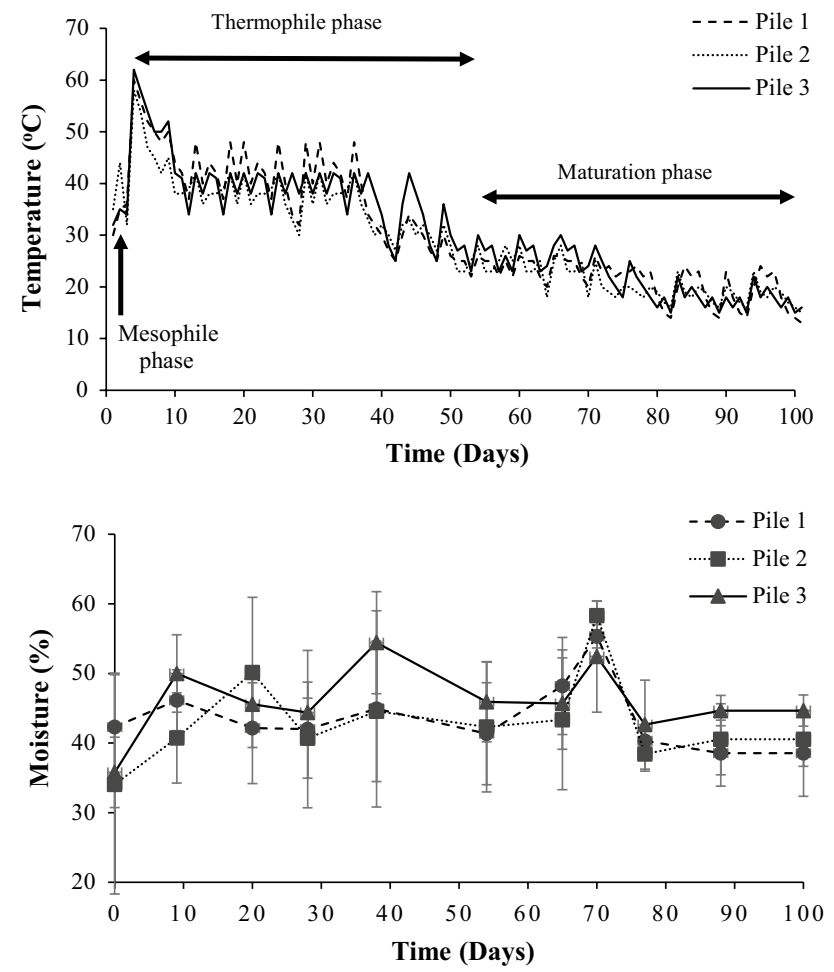

Fig. 2 Temperature $\mathbf{a}$ and moisture $\mathbf{b}$ measurements during the composting of onion waste mixed with cow dung. Bars indicate standard deviation $(n=3)$

\section{Results and discussion}

\section{Physicochemical evaluation of the onion waste composting process}

\section{Temperature and moisture profile}

Temperature is a key indicator of the various stages of the decomposition process of organic matter and determines the degree of stability of the final end product (Moreno-Casco and Mormeneo-Bernal 2011; Chin et al. 2020). Another important factor is moisture, which critically impacts microbial growth and metabolism within the composting pile. For instance, excess moisture reduces the porosity of the compost mix, generating an environment that enhances anaerobic growth (Márquez-Bueno and Díaz-Blanco 2007).

Temperature profiles recorded during the composting of onion waste and cow dung are shown in Fig. 2a. These data indicate that the mesophilic phase occurred over the first two composting days, the thermophilic phase took place between the 3rd and 45th days, and the maturation phase encompassed the remaining period up to the end of the assay (100 days). The three composting piles showed similar temperature profiles during the composting process. Compost temperature $\sim 60{ }^{\circ} \mathrm{C}$ by the $3 \mathrm{rd}$ day of the thermophilic phase, denoting high activity of the indigenous microbial population. This is in agreement with the general increase in the microbial population that occurs in the early stages of composting, reflecting adequate nutrients availability and suitable environmental conditions (Chin et al. 2020). During the thermophilic phase, temperature remained above $50{ }^{\circ} \mathrm{C}$ for 6 days. Several studies showed that temperature increments during composting increase the rate of organic matter conversion and reduce the population of pathogenic microorganisms (Dehghani et al. 2012; Sinhg et al. 2015; Tremier et al. 2005). After 8 more days, the temperature of the composting piles remained between 30 and $40{ }^{\circ} \mathrm{C}$ for the following 31 days. The piles were flipped on day 35 of composting in order to increase the porosity and oxygen availability in the composting material. This process increased microbial activity, as reflected by a small increment in temperature. After the thermophilic phase, the temperature gradually decreased to remain stable at around $15^{\circ} \mathrm{C}$ until the last day of composting.

Moisture levels ranged were between 34 and $42 \%$ at the initial time and increased up to $50 \%$ during the first 20 days (Fig. 2b). These values are in agreement with of 30-70\% moisture range recommended by Martínez-Nieto et al. (2011) for the initial composting stages. In this study, moisture fluctuations were controlled by sprinkler irrigation and set gradually over time at around $45 \%$. No significant differences in moisture content were observed for the three piles 

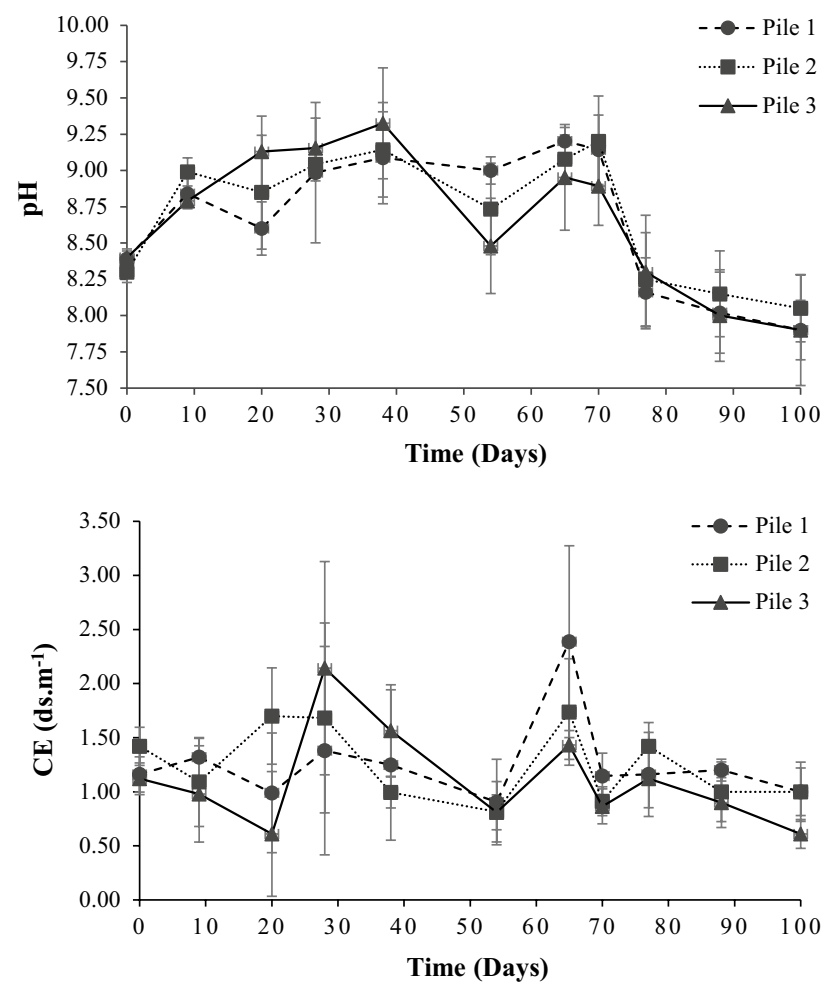

Fig. $3 \mathrm{pH}$ a and electrical conductivity (EC) $\mathbf{b}$ measured in the three piles during the composting of onion waste mixed with cow dung. Bars indicate standard deviation $(n=3)$

evaluated in the assay $(p \geq 0.05)$, except toward the end of the composting process (88-100 days) when the moisture of the composting pile 3 was significantly higher than that of piles 1 and $2(p \leq 0.05)$. However, this difference did not have obvious implications regarding final compost quality. Indeed, and as recommended by previous works (Guo et al. 2012; Richard et al. 2002), moisture content during the composting process ranged from of $40 \%-60 \%$ for the three piles. Moisture control is crucial during the composting piles to enhance microbial activity and aid in the decomposition of organic matter. Moisture values below 30\% inhibit microbial activity, preventing decomposition of organic material. Conversely, moisture levels above $65 \%$ decrease porosity and prevent adequate gas exchange, reducing oxygen availability and promoting the growth of anaerobes (Miyatake and Iwabuchi 2006).

\section{Variation of $\mathrm{pH}$ and electrical conductivity}

$\mathrm{pH}$ and $\mathrm{EC}$ are two of the main variables affecting compost quality. $\mathrm{pH}$ is an important parameter to assess the microbial environment of composting and the degree of stability reached by organic wastes. EC is an indicator of soluble salt content and is determined by the composition and nature of the feedstock.

The $\mathrm{pH}$ variations during the composting process are shown in Fig. 3a. Initial $\mathrm{pH}$ values for the three piles were very similar, (8.30-8.40) denoting the homogeneity of the corresponding onion waste / cow dung mixtures. In the mesophilic and thermophilic phases, $\mathrm{pH}$ values increased significantly $(p \leq 0.05)$ reaching maximum between days $38-77$ in the three piles. This increment can be attributed to degradation of organic acids and production of ammonium derived from protein degradation. Similar values of $\mathrm{pH}$ were obtained during the composting of hen manure (ÁlvarezVera et al. 2019). The decomposition of organic matter is inhibited at low $\mathrm{pH}$, hence $\mathrm{pH}$ values higher than 7.5 during the composting process are indicative of good environmental conditions (Dias et al. 2010; Pellejero et al. 2015). During the maturation phase, $\mathrm{pH}$ decreased due to removal of ammonium via nitrification (Cayuela et al. 2007; Villanueva 2015). Accordingly, a significant drop in $\mathrm{pH}$ (in excess of one $\mathrm{pH}$ unit) was detected during the last 30 days of the composting process. The final $\mathrm{pH}$ values recorded (close to 8.0), reflected in turn the maturity of the final compost (Varma and Kalamdhad 2014). Generally, the pH of compost piles increases at the beginning of the composting period and then shows a slight drop (Chin et al. 2020). Our results are in agreement with those achieved during the composting of vegetable waste mixed with cattle manure ( $\mathrm{pH} 7.7-8.0)$ (Sudharsan Varma and Kalamdhad 2015). Of note, a final product with $\mathrm{pH} 7.8$, similar to that registered in the present work, was obtained after vermicomposting of onion waste mixed with cow dung (Pellejero et al 2020).

The EC profiles for the three composting piles are shown in Fig. 3b. Although significant inter-sample differences in EC values were recorded at several time points, the three composting piles showed comparable EC profiles that tended to vary in parallel over the course of the composting process.

During the thermophilic phase (i.e., between days 3 and 45 of composting), the EC increased to reach $2.14 \mathrm{dS}$ $\mathrm{m}^{-1}$. EC elevations during this composting phase are due to decomposition of organic matter which determines an 

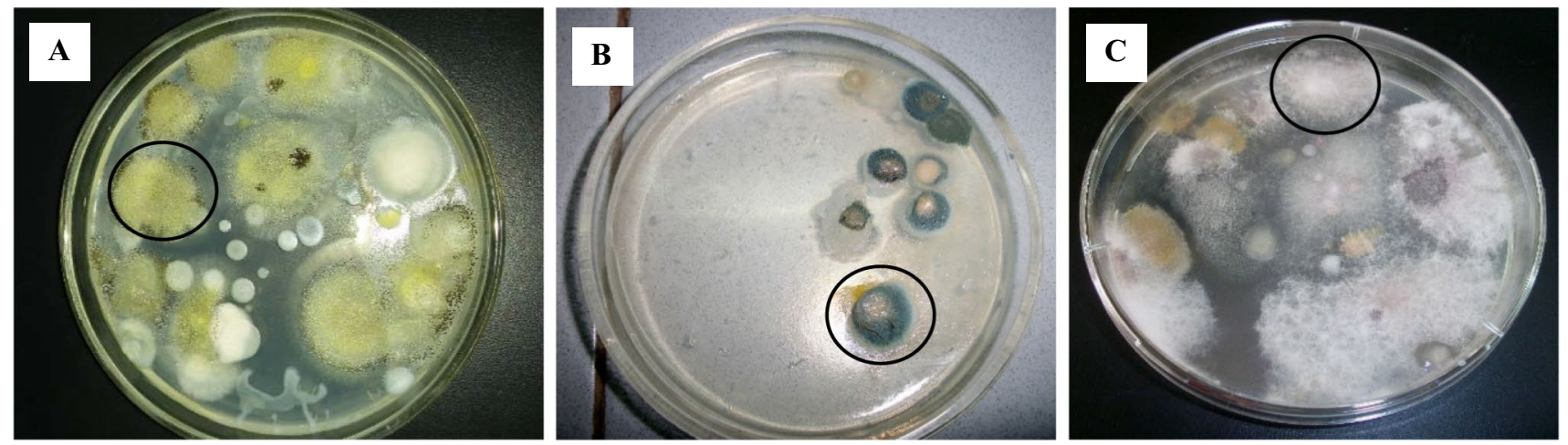

Fig. 4 Visual aspect of colonized petri dishes $(\varnothing 15 \mathrm{~mm})$ used for the identification and count of phytopathogenic fungi: Aspergillus niger a, Penicillium sp. b and Fusarium sp. c. Circles indicate colonies of the corresponding fungi

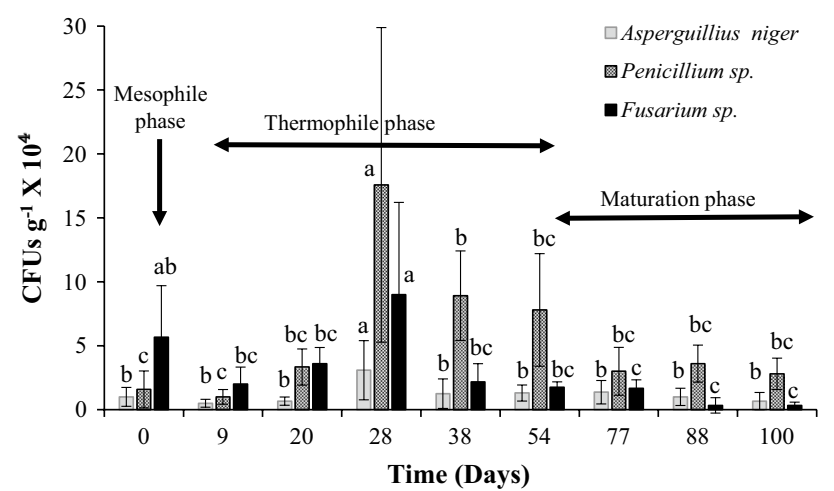

Fig. 5 Time course assessment of phytopathogenic fungi populations during the composting of onion waste and cow dung. Bars indicate standard deviation $(n=12)$. Different letters indicate significant differences among sampling days for each fungus (Tukey post hoc test, $p \leq 0.05)$

increase in soluble salt content that is not attenuated by leaching or binding to stable organic complexes (Dadi et al. 2019; Sudharsan Varma and Kalamdhad 2015). The EC of a compost mixture is primarily determined by its salts content, and by ions such as ammonium and nitrate, produced during the composting process (Sánchez-Monedero et al. 2001). At the transition between the thermophilic and the maturation phases, a second increment in EC was observed in the three piles, which likely resulted from the turning of the compost earlier on. From day 77 of composting and until the end of the process, EC decreased significantly $(p \leq 0.05)$. The decrease in $\mathrm{EC}$ at the maturation phase could be attributed to a reduction in soluble salts contents through leaching caused by irrigation of the piles (Alburquerque et al. 2006). The final EC of pile 3 was significantly lower than those recorded for piles 1 and 2 . This could be related to the higher moisture content of pile 3 at this point, and therefore, to increased salt leaching relative to piles 1 and 2 . Nevertheless, no significant issues are expected to arise from the agricultural application of any resulting composts.

\section{Assessment of phytopathogenic fungi during onion waste composting}

The presence of three soil-borne phytopathogenic fungi affecting post-harvest onions, i.e., A. niger, Penicillium sp. and Fusarium sp., during the composting of onion waste mixed with cow dung was analyzed by assessing CFU variation over time in water extracts from the three composting piles herein assayed. For the three fungal genera, CFU counts were performed at a $10^{-4}$ dilution, which provided the best visualization of individual colonies (Fig. 4). The corresponding data are shown in Fig. 5. The usefulness of this methodology is supported by studies assessing variations in microbiota composition associated with temperature changes during the different composting phases (MorenoCasco and Mormeneo-Bernal 2011). Our analysis showed that at the beginning of the composting process, namely during the mesophilic phase, the most abundant fungus was Fusarium sp. followed by Penicillium sp. and A. niger. Over the first days of the thermophilic phase (sampling day 9), the piles reached their maximum temperature $\left(58-62{ }^{\circ} \mathrm{C}\right)$ 
(Fig. 2a). Such high temperature rage, prolonged over several days is likely responsible for the observed decrease in the phytopathogenic fungi population. Despite relatively large reductions (between 37 and 65\%) in CFU counts from baseline to composting day 9 , the decrease was not significant for any fungus $(p>0.05)$.

For the three fungi, CFU counts increased significantly in the thermophilic phase between days 20 and 28 with temperatures below $50{ }^{\circ} \mathrm{C}(p \leq 0.05)$, reaching a maximum at 28 days of composting. In turn, a significant decrease in CFU numbers was observed in all three cases at subsequent sampling times $(p \leq 0.05)$. Previous research that indicated that Aspergillus sp. and Penicillium sp., followed by Trichoderma sp., Mucor sp., Rhizopus sp., Cladosporium sp., Backusella sp., Ulocladium sp., Acremonium sp., Fusarium sp., Scopulariopsis sp. and Geotrichum sp. are the predominant fungal genera in this composting phase (Anastasi et al. 2005; Haseena et al. 2016; Rouhullah et al. 2012). Our results are in good agreement with the above genera distribution and reproduce the noticeable fungal population reduction that is reported to occur as composting time progresses (MorenoCasco and Mormeneo-Bernal 2011). In our work, the maturation phase was characterized by a gradual decrease in the number of the phytopathogenic fungi which was toward the end of the process significantly $(p \leq 0.05)$ lower than in the previous phases. Chin et al. (2020) reported a significant (onefold to twofold) decrease in fungal population numbers and an increment of the Actinobacteria population in the last stages of the composting process. In this work, a marked decrease in the A. niger and especially the Fusarium sp. populations was evident in the final compost product, with both genera attaining CFU values of $<10^{4} \mathrm{CFU} \mathrm{g}^{-1}$. Of note, these values are lower than those reported by Anastasi et al. (2005). For all, the composting process of onion waste mixed with cow dung did not increase the abundance of the three phytopathogenic fungi. Moreover, this process significantly reduced the CFU of Fusarium sp.

The most abundant fungus in the final compost was Penicillium sp. According to Gómez-Griñán (2004), the presence of the genus Penicillium is beneficial, since it promotes the solubilization of phosphorous from organic matter by acid- and alkaline-phosphatases, acting therefore as a biostimulant.

\section{Implications for circular economy and organic farming}

The present work deals with the principles of the circular economy because two agricultural wastes, onion waste and cow dung, are recycled and reintroduced into the productive system as a new raw material, i.e., compost. Composting is one of the best and most sustainable methods of agricultural waste recycling because it allows reincorporating nutrients and organic matter into circulation while maintaining the waste-soil-plant production continuum (Jakubus 2020). The use of compost is within the scope of a sustainable agricultural system that provides an ecologically healthy and economically viable crop production, especially when the latter derives from low-value by-products of the cultivated plants (Kadoglidou et al. 2019). From an economic perspective, it should be underlined that raw materials used for composting are easily available locally. Thus, the final product is relatively cheap and marketable by farmers, providing a cost-effective alternative to commercial mineral fertilizers (Jakubus 2020).

There are multiple current and proved experiences of successful recycling of agricultural waste through composting. For example, Kadoglidou et al. (2019) reported that the application of compost from rice by-products on rice paddy fields satisfies crop nutrient requirements, without compromising yield and quality. Meanwhile, Duque-Acevedo et al. (2020) reported that self-management of horticultural waste by composting is profitable at real scale. Therefore, converting agricultural wastes into organic fertilizer helps to break the linearity of the traditional agricultural system and to close the loop for a more sustainable crop production. Hence, agricultural waste recycling for composting represents a feasible, cost-effective strategy to minimize the use of chemical fertilizers, reduce greenhouse emissions and enhance carbon sequestration with the consequent reduction in the environmental impact (Diacono et al. 2019; Thomas et al. 2019). However, for a full and wide-scale implementation of this practice, recycling policies must be enacted and reinforced at different government levels (Duque-Acevedo et al. 2020; Jakubus 2020). 


\section{Conclusion}

Our study shows the feasibility of turning discarded onion waste affected by phytopathogenic fungi into organic fertilizer suitable for agricultural practices. The physicochemical data collected during the 100 days composting of onion waste and cow dung indicate both a correct composting process and a stable compost product. Although further in-field testing is warranted, the adequate $\mathrm{pH}$ and moisture levels, as well as the low electrical conductivity, recorded over the process suggest that the compost produced in our work is adequate for agricultural input as organic fertilizer or amendment. Importantly, our work demonstrates that the composting of onion waste and cow dung in a ratio of approximately 1:1 does not act as multiplicator of phytopathogenic fungi. Moreover, the composting process presented herein was effective in reducing the presence of Fusarium sp., a phytopathogen of particular concern in onion production. Hence, the composting of onion waste and cow dung is a feasible and sustainable procedure to recycle onion waste and to promote circular economy in onion production regions. In the future is need to identify the patterns in the relationships between the microbial diversity and ecosystem services; also, quality standards are required in order to avoid phytotoxicity effects on plants.

Acknowledgements This work was carried out under the auspices of the Secretaria de Ciencia y Técnica of the Universidad Nacional del Comahue (Argentine). The authors are grateful for the contributions of the two anonymous reviewers to improve the article.

Authors' contribution AC, MCS, GP and RJ-B contributed to conceptualization; AC, JP and GA contributed to methodology; AC and MCS contributed to formal analysis and investigation; AC and CG-D contributed to writing - original draft preparation; AC, CG-D, MCS and RJ-B contributed to writing-review and editing; GP acquired funding; AC and JP provided resources; GP, MCS and RJ-B contributed to supervision.

Funding Open Access funding provided thanks to the CRUE-CSIC agreement with Springer Nature. This study was funded by Secretaria de Ciencia y Técnica of the Universidad Nacional del Comahue (Argentine).

Availability of data and material (data transparency) Under request.

Code availability (software application or custom code) Not applicable

\section{Declarations}

Conflict of interest The authors have no conflicts of interest to declare that are relevant to the content of this article.

Open Access This article is licensed under a Creative Commons Attribution 4.0 International License, which permits use, sharing, adaptation, distribution and reproduction in any medium or format, as long as you give appropriate credit to the original author(s) and the source, provide a link to the Creative Commons licence, and indicate if changes were made. The images or other third party material in this article are included in the article's Creative Commons licence, unless indicated otherwise in a credit line to the material. If material is not included in the article's Creative Commons licence and your intended use is not permitted by statutory regulation or exceeds the permitted use, you will need to obtain permission directly from the copyright holder. To view a copy of this licence, visit http://creativecommons.org/licenses/by/4.0/.

\section{References}

Abdoli MA, Omrani G, Safa M, Samavat S (2019) Comparison between aerated static piles and vermicomposting in producing co-compost from rural organic wastes and cow manure. Int J Environ Sci Technol 16:1551-1562

Alburquerque JA, Gonzálvez J, Cegarra J (2006) Composting of a solid olive mill by-product ("alperujo") and the potential of the resulting compost for cultivating pepper under commercial conditions. Waste Manag 26:620-626

Álvarez-Vera M, Largo A, Sergio-Iglesias S, Abad J (2019) Quality of compost obtained from hen manure, with application of beneficial microorganisms. Sci Agropecu 10:3

Anastasi A, Varese GC, Marchisio VF (2005) Isolation and identification of fungal communities in compost and vermicompost. Mycologia 97:33-44

Bremner SM (1996) Nitrogen total. In: Sparks DL (ed) Methods of soil analysis. Part 3. Chemical methods. ASA-SSSA, Madison, pp 1085-1121

Bueno-Márquez P, Díaz-Blanco MJ (2007) Factores que afectan al proceso de compostaje. In: Moreno-Carrasco J, Moral-Herrero R (eds) compostaje. Mundi-Prensa, Madrid, pp 95-109 ((in Spanish))

Carpio MJ, García-Delgado C, Marín-Benito JM, Sánchez-Martín MJ, Rodríguez-Cruz MS (2020a) Soil microbial community changes in a field treatment with chlorotoluron, flufenacet and diflufenican and two organic amendments. Agronomy 10:1166

Carpio MJ, Rodríguez-Cruz MS, García-Delgado C, Sánchez-Martín MJ, Marín-Benito JM (2020b) Mobility monitoring of two herbicides in amended soils : a field study for modeling applications. $\mathbf{J}$ Environ Manag 260:110161

Cayuela ML, Millner PD, Slovin J, Roig A (2007) Duckweed (Lemna gibba) growth inhibition bioassay for evaluating the toxicity of olive mil wastes before and during composting. Chemosphere 68:1985-1991

Chin KL, H'ng PS, Chai EW, Khoo PS, Lee CL, Go WZ (2020) Valorization of lignocellulosic food industry waste in Malaysia by accelerated co-composting method: changes in physicochemical and microbial community. Waste Biomass Valori 11:4871-4884

Chorolque A, Pozzo-Ardizzi C, Pellejero G, Aschkar G, GarciaNavarro FJ, Jiménez-Ballesta R (2018) Incidence of bacterial diseases associated with irrigation methods on onions (Allium сера). J Sci Food Agric 98:5534-5540

Cooperband L (2002) The art and science of composting. Center for Integrated Agricultural Systems, University of Wisconsin, Madison. (Available online at: https://cias.wisc.edu/2002/03/ 01/the-art-and-science-of-composting/) (verified 7 June 2021)

Coventry E, Noble R, Mead A, Whipps JM (2002) Control of allium white rot (Sclerotium cepivorum) with composted onion waste. Soil Biol Biochem 34:1037-1045

de Ceuster TJJ, Hoitink HAJ (1999) Prospects for composts and biocontrol agents as substitutes for methyl bromide in biocal control of plant diseases. Compost Sci Util 7:6-15 
Dehghani R, Asadi MA, Charkhloo E, Mostafaie G, Saffari M, Mousavi GA, Pourbabaei M (2012) Identification of fungal communities in producing compost by windrow method. $\mathrm{J}$ Environ Prot 3:61-67

Diacono M, Persiani A, Testani E, Montemurro F, Ciaccia C (2019) Recycling agricultural wastes and by-products in organic farming: biofertilizer production, yield performance and carbon footprint analysis. Sustainability 11:3824

Dias BO, Silva CA, Higashikawa FS, Roig A, Sanchez-Monedero MA (2010) Use of biochar as bulking agent for the composting of poultry manure: effect on organic matter degradation and humification. Bioresour Technol 101:1239-1246

Duque-Acevedo M, Belmonte-Ureña LJ, Plaza-Úbeda JA, Camacho-Ferre F (2020) The management of agricultural waste biomass in the framework of circular economy and bioeconomy: an opportunity for greenhouse agriculture in Southeast Spain. Agronomy 10:489

Entwistle AR (1990) Root diseases. In: Rabinowitch HD, Brewster JL (Eds) Onions and allied crops. Agronomy, biotic interactions, pathology and crop protection Vol. II, CRC Press, Boca Raton, pp 103-154

Gómez-Guiñan Y (2004) Actividad de las fosfatasas ácidas y alcalinas (extracelulares e intracelulares) en hongos de la rizosfera de Arachyshipogea (Papiloneaceae). Rev De Biol Trop 52:287295 ((in Spanish))

Guo R, Li G, Jiang T, Schuchardt F, Chen T, Zhao Y, Shen Y (2012) Effect of aeration rate, $\mathrm{C} / \mathrm{N}$ ratio and moisture content on the stability and maturity of compost. Bioresour Technol 112:171-178

Hadar Y, Gorodecki B (1991) Suppression of germination of sclerotia of Sclerotium rolfsii in compost. Soil Biol Biochem 23:303-306

Haseena A, Nishad VM, Balasundaran M (2016) A consortium of thermophilic microorganisms for aerobic composting. IOSR J Environ Sci Toxicol Food Technol 10:49-56

Instituto de Desarrollo del Valle Inferior (IDEVI). Declaración jurada de los cultivo en la temporada 2016-2017. (in Spanish)

Jakubus M (2020) A comparative study of composts prepared from various organic wastes based on biological and chemical parameters. Agronomy 10:869

Kadoglidou K, Kalaitzidis A, Stavrakoudis D, Mygdalia A, Katsantonis D (2019) A novel compost for rice cultivation developed by rice industrial by-products to serve circular economy. Agronomy 9:553

Kumar V, Sharma NS, Sagar NA (2015) Post harvest management of fungal diseases in onion. A review. Inter J Curr Microbiol Appl Sci 4:737-752

Lee JT, Bae DW, Park SH, Shim CK, Kwak YS, Kim HK (2001) Occurrence and biological control of postharvest decay in onion caused by fungi. Plant Pathol J 17:141-148

Miyatake F, Iwabuchi K (2006) Effect of compost temperature on oxygen uptake rate, specific growth rate and enzymatic activity of microorganisms in dairy cattle manure. Bioresour Technol 97:961-965

Mondini C, Sequi P (2008) Implication of soil C sequestration on sustainable agriculture and environment. Waste Manag 28:678-684

Moreno-Casco JM, Mormeneo-Bernal S (2011) Microbiología y Bioquímica del proceso de Compostaje. Ediciones Mundi-Prensa, Madrid, Spain, p p550 (in Spanish)

Pellejero G, Pozzo-Ardizzi MC, Aschkar G (2011) Determination of the presence and quantification of Aspergillus niger in onion waste compost. XXXIV Argentina Congress of Horticulture, Buenos Aires
Pellejero G, Pozzo-Ardizzi C, Aschkar G, Chorolque A, Jiménez Ballesta R (2015) Quality assessment by Aspergillus niger of an onion, cattle manure and alfalfa waste compost blend. Inter J Plant Soil Sci 8:1-8

Pellejero G, Miglierina A, Aschkar G, Turcato M, Jimenez-Ballesta $R$ (2017) Effects of the onion residue compost as an organic fertilizer in a vegetable culture in the Lower Valley of the Rio Negro. Inter J Recycl Org Waste Agric 6:159-166

Pellejero G, Rodriguez K, Ashchka G, Vela E, García-Delgado C, Jiménez-Ballesta R (2020) Onion waste recycling by vermicomposting : nutrients recovery and agronomical assessment. Int $\mathbf{J}$ Environ Sci Technol 17:3289-3296

Pugliese M, Liu BP, Gullino ML, Garibaldi A (2008) Selection of antagonists from compost to control soil-borne pathogens. J Plant Dis Prot 115:220-228

Richard TL, Hamelers HVM, Veeken A, Silva T (2002) Moisture relationships in composting processes. Compost Sci Util 10:286-302

Román P, Martinez MM, Pantoja A (2015) Farmer's Compost Handbook. Experiences in Latin America. Food and Agricultural Organization of the United Nations (FAO) Santiago. http://www. fao.org/3/a-i3388e.pdf

Rouhullah D, Mohammad AA, Esmail C, Gholamreza M, Mohmoud S, Gholam AM, Mohammad P (2012) Identification of fungal communities in producing compost by windrow method. J Environ Prot 3:61-67

Rynk R, Van de Kamp M, Willson GB, Singley ME, Richard TL, Kolega JJ, Gouin FR, Laliberty Jr, Kay D, Murphy DW, Hointink HAJ, Brinton WF (1992) On-farm Composting Handbook. Northeast Regional Agricultural Engineering Service, Ithaca

Samuel O, Ifeanyi O (2015) Fungi associated with the deterioration of post-harvest onion bulbs sold in some markets in Awka, Nigeria. Bioeng Biosci 3:90-94

Sánchez AD, Barrera V, Reybet GE, Sosa MC (2015) Biocontrol with Trichoderma spp. against Fusarium oxysporum causal of "damping off" in pre and post emergence in onion. Rev Fac Agron 114:61-70

Sánchez-Monedero M, Roig A, Paredes C, Bernal P (2001) Nitrogen transformation turing organic waste composting by the rutgers system and its effects on $\mathrm{pH}, \mathrm{EC}$ and maturity of the composting mixture. Bioresour Technol 78:301-308

Sudharsan Varma V, Kalamdhad AS (2015) Evolution of chemical and biological characterization during thermophilic composting of vegetable waste using rotary drum composter. Inter J Environ Sci Tech 12:2015-2024

Thomas CL, Acquah GE, Whitmore AP, McGrath SP, Haefele SM (2019) The effect of different organic fertilizer on yield and soil and crop nutrient concentrations. Agronomy 9:776

Tremier A, de Guardia A, Massiani C, Paul E, Martel JL (2005) A respirometric method for characterising the organic composition and biodegradation kinetics and the temperature influence on the biodegradation kinetics, for a mixture of sludge and bulking agent to be co-composted. Bioresour Technol 96:169-180

Trombetta A, Accotto E, Belfiore G, Piccone G, Pantusa S, Nappi P, Barberis R (1998) Metodi di analisi dei compost. Determinazioni chimiche, fisiche, biologiche e microbiologiche. Analisi merceologica dei rifiuti. Regione Piemonte, Assessorato Ambiente. Collana ambiente, Turin

Tysoni JL, Fullerton RA (2004) Effect of soil borne inoculums on incidence of onion black mold (Aspergillus niger). New Zealand Plant Prot 57:138-141 
Vargas Machuca R, Romero-Taboada E, Fernández-Gomes M (2015) De residuos a recursos. El Camino hacia la Sostenibilidad. MundiPrensa, Cádiz ((in Spanish))

Varma VS, Kalamdhad A (2014) Evolution of chemical and biological characterization during thermophilic composting of vegetable waste using rotary drum composter. Int J Environ Sci Technol 12:2015-2024
Villanueva D (2015) Descomposición de la biomasa de residuos orgánicos bajo un sistema de compostaje abierto y cerrado. BioSci 2:21-30 ((in Spanish))

Yuen GY, Raabe RD (1984) Effects of small-scale aerobic composting on survival of some fungal plant pathogens. Plant Dis 68:132-136 